\title{
COMPARITIVE STUDY ON RCC AND COMPOSITE (CFT) MULTI- STOREYED BUILDINGS
}

\author{
Faizulla Z Shariff ${ }^{1}$, Suma Devi ${ }^{2}$ \\ ${ }^{I}$ Post Graduate student, Structural Engineering, SVCE Bangalore, Karnataka, India \\ ${ }^{2}$ Assistant Professor, Civil Engineering, SVCE Bangalore, Karnataka, India
}

\begin{abstract}
In India reinforced concrete structures are mostly used since this is the most convenient \& economic system for low-rise buildings. However, for medium to high-rise buildings this type of structure is no longer economic because of increased dead load, less stiffness, span restriction and hazardous formwork. So the structural engineers are facing the challenge of striving for the most efficient and economical design solution. Use of composite material is of particular interest, due to its significant potential in improving the overall performance through rather modest changes in manufacturing and constructional technologies. Steel-concrete composite columns are used extensively in modern buildings. Extensive researches on composite columns in which structural steel section are encased in concrete have been carried out. In-filled composite columns, however have received limited attention compared to encased columns. In this study E-Tabs nonlinear software is used for simulation of steel concrete composite (CFT) with steel reinforced concrete structures $(R C C)$ of $G+14, G+19$ and $G+24$ stories each are considered for comparative study. Comparison of parameters like time period, storey displacement and storey drift is done.
\end{abstract}

Keywords: Composite CFT columns, bracings, shear wall, time period, storey displacement and storey drift.

\section{INTRODUCTION}

In today's modern world of creativity, two materials most certainly used as building material those are steel and concrete for structures ranging from sky scrapers to pavements, although these materials possess different characteristics and properties, they both like to complement each other in various ways. Steel has excellent resistance to tensile loading but has lesser weight ratio so slender sections are used which may be dangerous to buckling phenomenon and on the other hand concrete is good in compression. Steel may be used to influence ductility which is an important aspect for high rise building, on the other hand corrosion prevention and thermal insulation can be done by concrete. Identically buckling of steel can also be restrained by concrete. Significantly, to bring the minimum benefits from both materials, composite construction is largely preferred. In construction of composite structures two types of columns are used they are encased column and concrete filled steel tube column.

\subsection{Reinforced Concrete}

Reinforced concrete consists of steel and concrete which are combined together to act as a composite material where steel helps in taking both compression and tension whereas concrete can withstand only compression. RCC is a structural material which is widely used in many kinds of structures. It is involving with steel even though economically designed and executed.

\section{Advantages of Reinforced Concrete}

1) Reinforced concrete has larger compression as compared to most other materials used for construction apart from good in tension.

2) It has greater resistance to fire than steel and ability of resisting fire for a extended period of time.

3) It has lengthy service life with very little maintenance cost.

4) It can appear to take the shape needed, made largely used in pre-cast structural elements.

5) It yields stiff members with least apparent deflection.

6) Yield strength of steel is nearly fifteen times the compressive strength of structural concrete and is higher than hundred times its tensile strength.

\section{Disadvantages of Reinforced Concrete}

1) It requires necessity of mixing, casting and curing of concrete, all of which it influence the final strength of concrete.

2) The price of the forms used to cast concrete is relatively up.

3) It has less compression to steel where the ratio is about 1:10 depending on material which leads to big sections in beams or columns of multi-storey buildings. Cracks are developed in concrete due to shrinkage and in the application of live loads.

\subsection{Composite Column}

A steel concrete composite column is a compression member, comprising either of a concrete encased hot rolled steel section or a concrete filled hollow section of hot rolled steel. It is generally used as a load bearing member in a 
composite framed structure. Composite columns with fully and partially concrete encased steel sections concrete filled tubular section are generally used in composite construction.

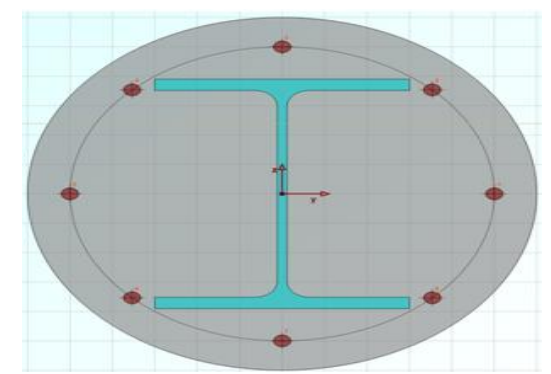

Composite encased I section Column

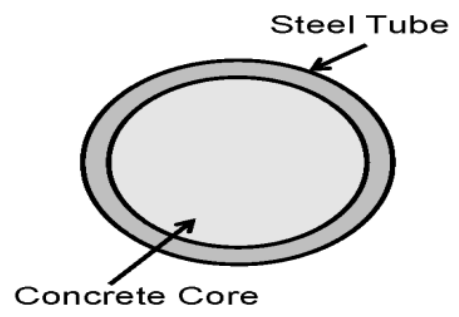

Concrete filled tube steel section column

\subsection{Concrete-Filled Tube (CFT)}

Concrete-filled steel tube (CFT) columns consist of a steel tube filled with concrete. The concrete core adds compressive strength and stiffness to the tubular column which reduces possible for inward local buckling. The steel tube acts as longitudinal and lateral reinforcement for the concrete core helping it to resist bending moment, shear force and twisting moment which provides confinement for the concrete.

Since the benefit of these composite action of two such materials, CFT columns provide better seismic resistant structural properties such as rise in ductility, increase in strength and enormous energy absorption capacity. Round hollow sections also possess many advantages over open sections which includes architectural enhancements and an economical term in cost of materials.

Due to the difficulty of connections between circular hollow sections and steel beams, their utility in structural steel work is minimum and this is because of the use of standard bolting is not feasible and not much economical so welded connections are the normal solution.

The advantages of CFT column when compared to other composite materials include:

1) The steel tube provides formwork for the concrete,

2) The concrete prolongs the buckling of the steel tube wall,

3) The excessive concrete spalling is prohibited by the tube and,

4) Composite columns extend the stiffness of a frame compared to more old steel frame construction.
While number of advantages exists, the use of Concrete filled steel tubes (CFT) in building construction has been minimum, it creates lack of construction experience, understanding of the design codes and the complexibility of connection illustrations. Perhaps, a joint is needed that could use the better strength and stiffness properties of the concrete-filled tube column yet be constructible.

\subsection{Bracing}

Bracing systems furnish lateral stability to the total frame work. The bracing members of similar braced frame act as a truss system to withstand lateral forces and are subjected mainly to axial stress in the elastic limit. It is easily seen that bare frames are found to be more pliable and have large section necessity to resist forces induced.

Braced frames acquire their lateral forces by the bracing acts of diagonal members. The main objective of bracing system is to withstand lateral forces. Braced ones have few forces induced in the structure and at the same time produce large displacement within prescribed range. Bracing system reduces shear force and bending moment in the columns.

\subsection{Shear Wall}

Shear wall is a structural framework acts as a rigid vertical diaphragm efficient of conveying horizontal forces from roofs, floors and from exterior walls to the base with their planes in parallel direction. Such kinds of examples are vertical truss or reinforced-concrete wall. Horizontal forces are produced by earthquake, wind and non-uniform loads. In addition to building weight and its occupants, it creates huge twisting forces. These forces can actually tear a building apart. By placing rigid wall inside a Reinforcing frame, it maintains the shape of the model and avoids rotation at the joints. Shear walls are more important in tall buildings subjected to seismic forces and wind forces.

\section{METHODOLOGY}

In the present study lateral load analysis as per the seismic code for the following type of structure such as bare frame, $\mathrm{X}$ bracing, $\mathrm{V}$ bracing, inverted $\mathrm{V}$ bracing, forward and backward diagonal bracings and also for shear wall has been carried out. All the above models were analyzed and results are compared to know the efficiency and strength of the structure by equivalent static method of analysis, response spectrum method of analysis and time history procedure. The analysis is carried out using ETABS software. In this study E-Tabs nonlinear software is used for simulation of steel concrete composite (CFT) with steel reinforced concrete structures (RCC) of G+14, G+19 and G+24 stories each are considered for comparative study. The required material properties like mass, weight, density, modulus of elasticity, shear modulus and design values of the material used can be modified as per requirements can be accepted. Beams and column members have been defined as frame elements and the columns have been restrained in all six degrees of freedom at the base. Slabs are defined as area elements having the properties of membrane elements and 
have been modelled as rigid diaphragms. Also concentric

bracings and shear walls are defined as frame elements and shell area elements respectively.

Table 1: Details of material properties, structural configuration and seismic data

\begin{tabular}{|c|c|c|}
\hline & CFT building & RCC building \\
\hline \multicolumn{3}{|l|}{ MATERIAL PROPERTIES } \\
\hline Grade of Concrete [fck] & $\mathrm{M}-30$ & $\mathrm{M}-30$ \\
\hline Grade of Reinforcing Steel [fy] & Fe-415 & Fe-415 \\
\hline Grade of Structural Steel & $340 \mathrm{~N} / \mathrm{mm}^{2}$ & - \\
\hline Unit wt. of Concrete & $25 \mathrm{kN} / \mathrm{m}^{3}$ & $25 \mathrm{kN} / \mathrm{m}^{3}$ \\
\hline \multicolumn{3}{|l|}{ SECTIONAL PROPERTIES } \\
\hline Column size & $\mathrm{D}=800 \& \mathrm{t}=9 \mathrm{~mm}$ & $\mathrm{D}=750 \mathrm{~mm}$ \\
\hline Beam size & ISWB600 & $250 \times 550$ \\
\hline Bracing size & ISMC200 & $200 \times 300$ \\
\hline Shear wall thickness & $200 \mathrm{~mm}$ & $200 \mathrm{~mm}$ \\
\hline Slab thickness & $150 \mathrm{~mm}$ & $150 \mathrm{~mm}$ \\
\hline \multicolumn{3}{|l|}{ BUILDING PLAN } \\
\hline No. of bays in X-direction & 8 & 8 \\
\hline No. of bays in Y-direction & 6 & 6 \\
\hline Width of bay in X-direction & $6 \mathrm{~m}$ & $6 \mathrm{~m}$ \\
\hline Width of bay in Y-direction & $5 \mathrm{~m}$ & $5 \mathrm{~m}$ \\
\hline Height of Storey & $3 \mathrm{~m}$ & $3 \mathrm{~m}$ \\
\hline \multicolumn{3}{|l|}{ LOAD ASSIGNMENT } \\
\hline Live Load on roof slab & $1.5 \mathrm{kN} / \mathrm{m}^{2}$ & $1.5 \mathrm{kN} / \mathrm{m}^{2}$ \\
\hline Live Load on floor slab & $2 \mathrm{kN} / \mathrm{m}^{2}$ & $2 \mathrm{kN} / \mathrm{m}^{2}$ \\
\hline Weathering Course & $1 \mathrm{kN} / \mathrm{m}^{2}$ & $1 \mathrm{kN} / \mathrm{m}^{2}$ \\
\hline Floor finishing & $1 \mathrm{kN} / \mathrm{m}^{2}$ & $1 \mathrm{kN} / \mathrm{m}^{2}$ \\
\hline \multicolumn{3}{|l|}{ SEISMIC DATA } \\
\hline Seismic Zone & $\mathrm{V}$ & \\
\hline Importance Factor, I & 1 & \\
\hline Response Reduction Factor, R & 5 (SMRF) & \\
\hline Soil Type & Medium Soil & \\
\hline Response Spectrum Function & IS 1893:2002 Spectrum & \\
\hline Function Damping Ratio & 0.05 & \\
\hline Time History Function & Elcentro & \\
\hline
\end{tabular}

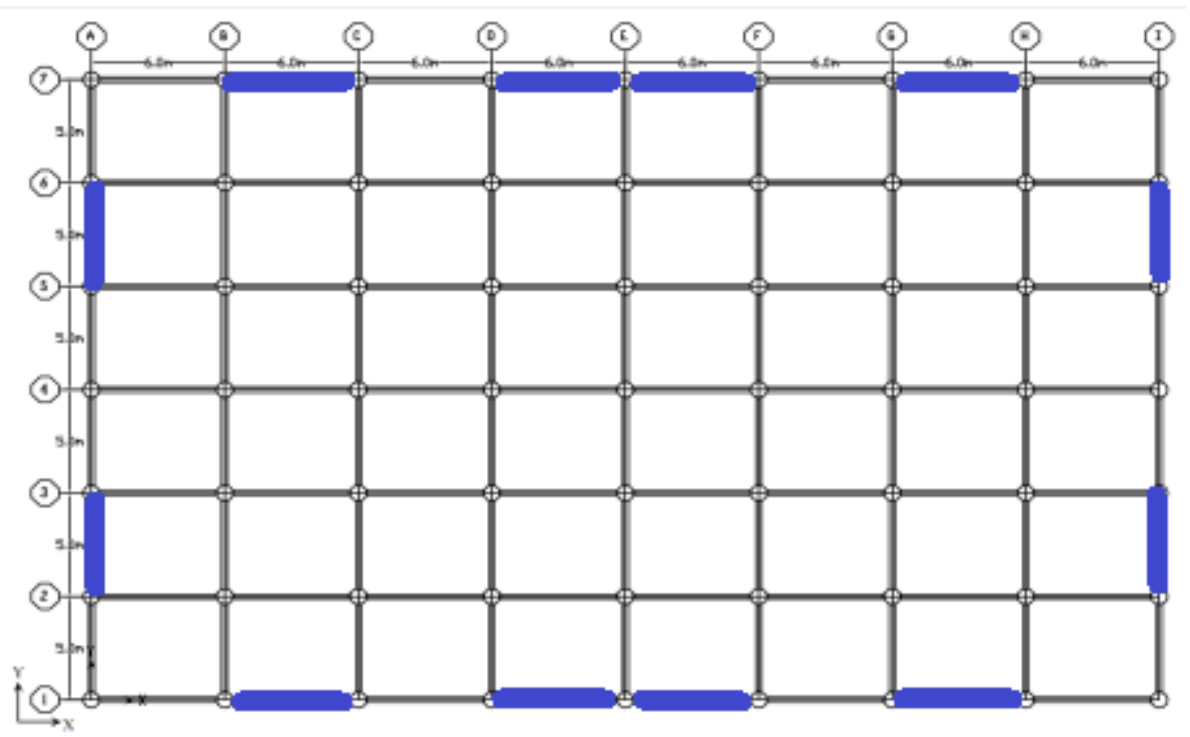

Fig 1: Plan Layout showing the location of different types of bracings and shear wall for RCC and CFT building 


\section{RESULTS AND DISCUSSIONS}

Most of the past studies on different buildings such symmetrical and unsymmetrical have adopted idealized structural systems with different bracings. Although these systems are sufficient to understand the general behaviour and dynamic characteristics, it would be interesting to know how real building will respond to earthquake forces. For this reason a hypothetical building, located on a plane ground having similar ground floor plan have been taken as structural systems for the study.

The results of natural time period of vibration, storey drift, lateral displacements and overall performance of different building models are presented and compared.

\subsection{Fundamental Natural Time Period and Frequency}

Natural Time Period of a building is the time taken by it to undergo one complete cycle of oscillation. It is an inherent property of a building controlled by its mass and stiffness. Its units are seconds (s). Thus, buildings that are heavy with larger mass and flexible with smaller stiffness have larger natural period than light and stiff buildings. The reciprocal of natural period of a building is called the Natural Frequency. Its unit is Hertz (Hz). The building offers least resistance when shaken at its natural frequency. Hence, it undergoes larger oscillation when shaken at its natural frequency than at other frequencies.

Table 2: Comparison of Time Period and Frequency for 15 Storey RCC and CFT Buildings

\begin{tabular}{|c|c|c|c|c|}
\hline \multirow{3}{*}{ Frame System } & \multicolumn{4}{|c|}{ Type of Structure } \\
\hline & \multicolumn{2}{|l|}{ RCC } & \multicolumn{2}{|l|}{ CFT } \\
\hline & $\begin{array}{l}\text { TIME } \\
\text { PERIOD(s) }\end{array}$ & FREQUENCY $(\mathrm{Hz})$ & TIME PERIOD(s) & FREQUENCY $(\mathrm{Hz})$ \\
\hline BARE FRAME & 2.58326 & 0.38711 & 1.77954 & 0.56194 \\
\hline X BRACED & 2.04171 & 0.48978 & 1.60622 & 0.62258 \\
\hline V BRACED & 2.08606 & 0.47937 & 1.62312 & 0.6161 \\
\hline INV V BRACED & 2.04976 & 0.48786 & 1.61653 & 0.61861 \\
\hline FD BRACED & 2.1379 & 0.46775 & 1.65433 & 0.60447 \\
\hline BD BRACED & 2.1379 & 0.46775 & 1.65433 & 0.60447 \\
\hline SHEAR WALL & 1.79493 & 0.55713 & 1.35726 & 0.73678 \\
\hline
\end{tabular}

TIME PERIOD (s)
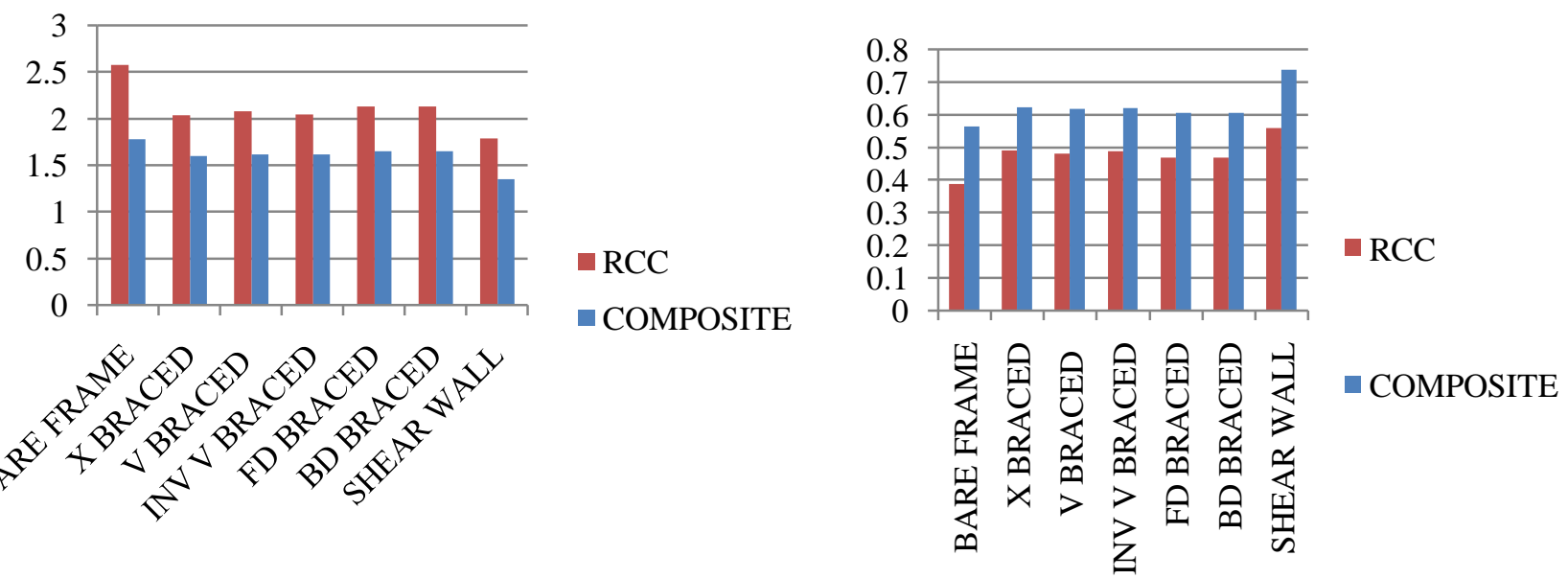

Chart 1: Time Period and Frequency for 15 Storey RCC and CFT Building 
Table 3: Comparison of Time Period and Frequency for 20 Storey RCC and CFT Buildings

\begin{tabular}{|l|l|l|l|l|l|}
\hline \multirow{2}{*}{ Frame System } & \multicolumn{2}{l}{ Type of Structure } \\
\cline { 2 - 3 } & RCC & \multicolumn{2}{l|}{ CFT } \\
\cline { 2 - 3 } & TIME PERIOD(s) & FREQUENCY(Hz) & \multicolumn{2}{l|}{ TIME PERIOD(s) } & FREQUENCY(Hz) \\
\hline BARE FRAME & 3.49874 & 0.28582 & 2.41454 & 0.41416 \\
\hline X BRACED & 2.85109 & 0.35074 & 2.20127 & 0.45428 \\
\hline V BRACED & 2.89667 & 0.34522 & 0.45017 \\
\hline INV V BRACED & 2.83993 & 0.35212 & 2.22141 & 0.45182 \\
\hline FD BRACED & 2.95164 & 0.33879 & 2.21325 & 0.44251 \\
\hline BD BRACED & 2.95164 & 0.33879 & 2.25984 & 0.44251 \\
\hline SHEAR WALL & 2.58836 & 0.38635 & 2.25984 & 0.5158 \\
\hline
\end{tabular}

TIME PERIOD (s)

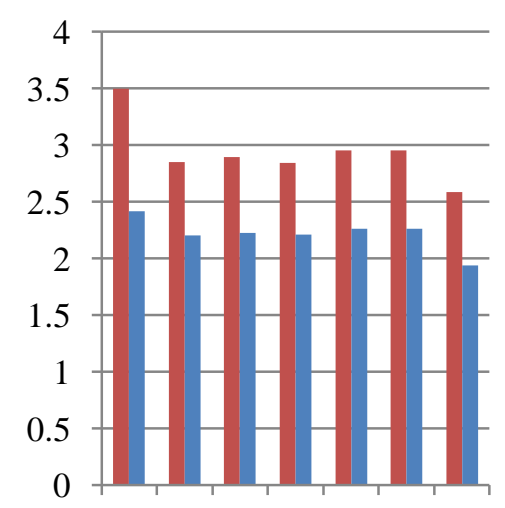

- RCC

- COMPOSITE

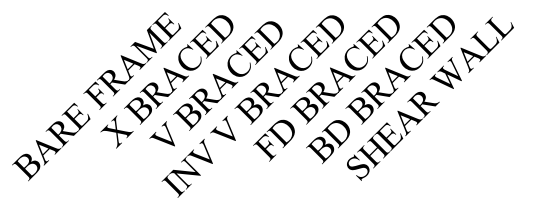

FREQUENCY (Hz)
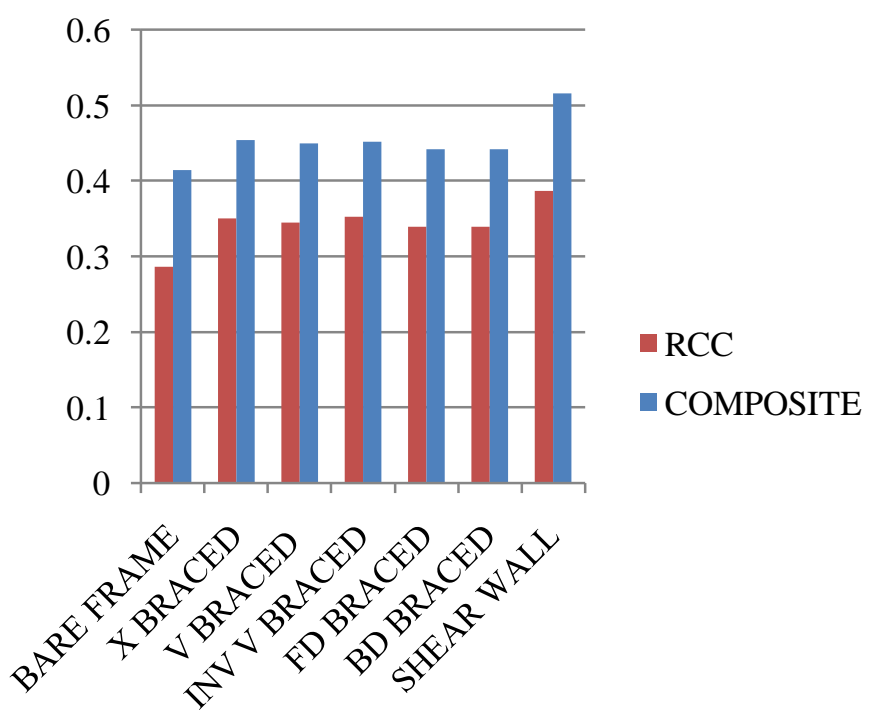

Chart 2: Time Period and Frequency for 20 Storey RCC and CFT Buildings

Table 4: Comparison of Time Period and Frequency for 25 Storey RCC and CFT Buildings

\begin{tabular}{|c|c|c|c|c|}
\hline \multirow{3}{*}{ Frame System } & \multicolumn{4}{|l|}{ Type of Structure } \\
\hline & \multicolumn{2}{|l|}{ RCC } & \multicolumn{2}{|l|}{ CFT } \\
\hline & TIME PERIOD(s) & FREQUENCY $(\mathrm{Hz})$ & TIME PERIOD(s) & FREQUENCY $(\mathrm{Hz})$ \\
\hline BARE FRAME & 4.42475 & 0.226 & 3.05897 & 0.32691 \\
\hline X BRACED & 3.70024 & 0.27025 & 2.81999 & 0.35461 \\
\hline V BRACED & 3.74487 & 0.26703 & 2.8425 & 0.3518 \\
\hline INV V BRACED & 3.68432 & 0.27142 & 2.83308 & 0.35297 \\
\hline FD BRACED & 3.80051 & 0.26312 & 2.8869 & 0.34639 \\
\hline BD BRACED & 3.80051 & 0.26312 & 2.8869 & 0.34639 \\
\hline SHEAR WALL & 3.42073 & 0.29234 & 2.54846 & 0.39239 \\
\hline
\end{tabular}


TIME PERIOD (s)

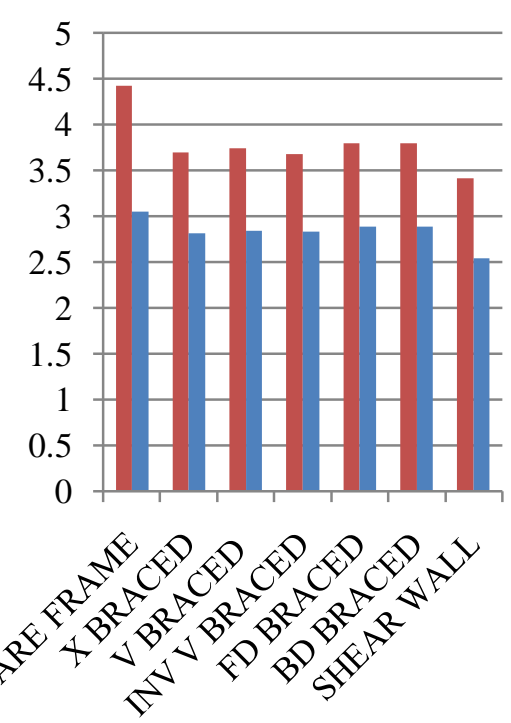

FREQUENCY (Hz)
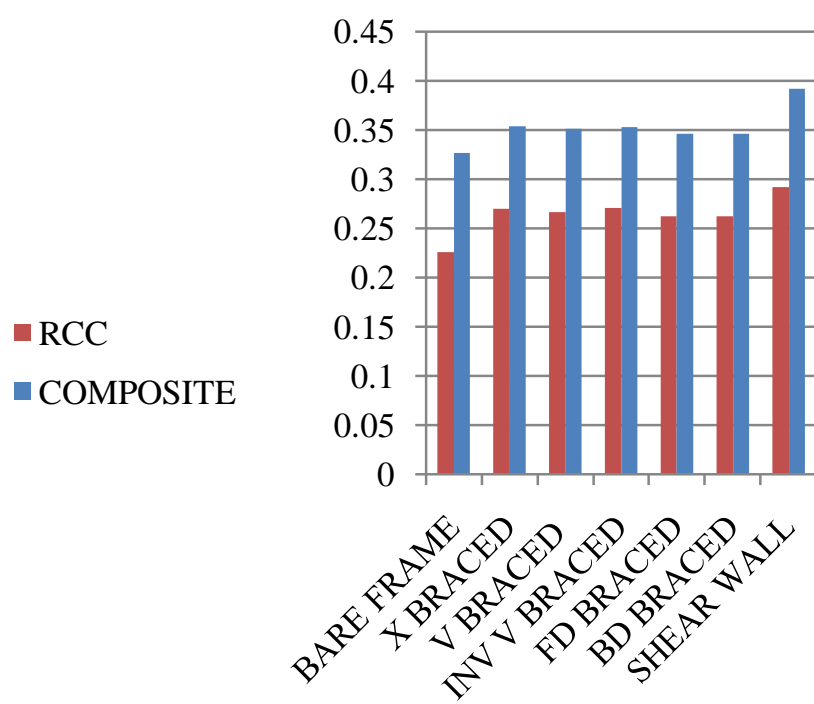

- RCC

COMPOSITE

Chart 3: Time Period and Frequency for 25 Storey RCC and CFT Building

It can be seen from table:1, 2 and 3 and chart:1, 2 and 3, fundamental time period and frequency values for bare frame with bracings and shear wall are analysed for 15, 20 and 25 storeys of RCC and CFT buildings in ETABS software. Natural time period value is increased for bare frame compared to bracings and shear wall in RCC buildings and time period value gets decreased for CFT composite buildings. Therefore bracings of different shapes and shear wall considerably influence the overall performance of RCC and CFT framed structures.

\subsection{Storey Displacement}

The maximum displacement at each floor level with respect to ground is examined in tables obtained from equivalent static analysis, response spectrum analysis and time history analysis. For better compatibility, the displacement for each model is taken along the longitudinal and transverse direction of ground motion which is plotted in charts below.

Table 5: Comparison of Top Storey Displacement for RCC Buildings

\begin{tabular}{|c|c|c|c|c|c|c|c|c|c|}
\hline & & & $\begin{array}{l}\text { BARE } \\
\text { FRAME }\end{array}$ & X BRACE & V BRACE & $\begin{array}{ll}\text { INV } & \text { V } \\
\text { BRACE }\end{array}$ & FD BRACE & BD BRACE & $\begin{array}{l}\text { SHEAR } \\
\text { WALL }\end{array}$ \\
\hline \multirow{6}{*}{ 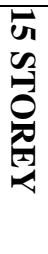 } & \multirow{2}{*}{ ESA } & $\mathbf{X}$ & 59.1 & 42.2 & 42.8 & 41.5 & 45 & 45 & 34.4 \\
\hline & & $\mathbf{Y}$ & 56.5 & 50.4 & 50.9 & 50.3 & 51.1 & 51.1 & 48.4 \\
\hline & \multirow{2}{*}{ RSA } & $\mathbf{X}$ & 41.8 & 29.1 & 29.5 & 28.5 & 31.5 & 31.5 & 17.7 \\
\hline & & $\mathbf{Y}$ & 40 & 34.8 & 35.5 & 34.9 & 36 & 36 & 25.5 \\
\hline & \multirow[b]{2}{*}{ THA } & $\bar{X}$ & 466.9 & 155.3 & 150.5 & 160.6 & 195.6 & 195.6 & 142.3 \\
\hline & & $Y$ & 434.4 & 236.3 & 265.5 & 240.9 & 292.4 & 292.4 & 170.6 \\
\hline \multirow{6}{*}{ 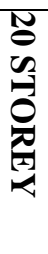 } & \multirow[b]{2}{*}{ ESA } & $\mathbf{X}$ & 80.1 & 60.3 & 60.9 & 59.6 & 63.1 & 63.1 & 52.4 \\
\hline & & $\mathbf{Y}$ & 77.4 & 70.7 & 71.1 & 70.8 & 71.3 & 71.3 & 68.7 \\
\hline & \multirow{2}{*}{ RSA } & $\mathbf{X}$ & 56.3 & 41.5 & 41.9 & 40.9 & 43.9 & 43.9 & 26.9 \\
\hline & & $\mathbf{Y}$ & 54.6 & 48.8 & 49.2 & 48.8 & 49.5 & 49.5 & 36.6 \\
\hline & \multirow[b]{2}{*}{ THA } & $\mathbf{X}$ & 551.8 & 446 & 459.2 & 423.4 & 495.1 & 495.1 & 190.7 \\
\hline & & $Y$ & 559.1 & 508.9 & 517.2 & 511.2 & 532.1 & 532.1 & 496.4 \\
\hline \multirow{6}{*}{ 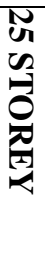 } & \multirow{2}{*}{ ESA } & $\mathbf{X}$ & 112.5 & 79.1 & 79.6 & 78.4 & 81.9 & 81.9 & 71.2 \\
\hline & & $\mathbf{Y}$ & 105.5 & 92 & 92.3 & 92.3 & 92.4 & 92.4 & 89.3 \\
\hline & \multirow{2}{*}{ RSA } & $\mathbf{X}$ & 78.8 & 53.8 & 54.4 & 53.1 & 56.7 & 56.7 & 36.6 \\
\hline & & $\mathbf{Y}$ & 73.8 & 63.1 & 63.6 & 63.2 & 64 & 64 & 47.6 \\
\hline & \multirow{2}{*}{ THA } & $\mathbf{X}$ & 370.7 & 569.1 & 571.7 & 563.8 & 594.8 & 594.8 & 485.1 \\
\hline & & $\mathbf{Y}$ & 415.4 & 566.7 & 550.8 & 562.5 & 531.5 & 531.5 & 585.1 \\
\hline
\end{tabular}


Table 6: Comparison of Top Storey Displacement for CFT Buildings

\begin{tabular}{|c|c|c|c|c|c|c|c|c|c|}
\hline & & & $\begin{array}{l}\text { BARE } \\
\text { FRAME }\end{array}$ & X BRACE & V BRACE & $\begin{array}{l}\text { INV } \\
\text { BRACE }\end{array}$ & FD BRACE & BD BRACE & $\begin{array}{l}\text { SHEAR } \\
\text { WALL }\end{array}$ \\
\hline \multirow{6}{*}{ 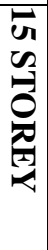 } & \multirow{2}{*}{ ESA } & $\mathbf{X}$ & 40.8 & 35 & 35.2 & 34.9 & 37.1 & 37.1 & 26.8 \\
\hline & & $\mathbf{Y}$ & 39.9 & 37.5 & 37.7 & 37.6 & 38.3 & 38.3 & 35.6 \\
\hline & \multirow{2}{*}{ RSA } & $\mathbf{X}$ & 28.7 & 24.7 & 24.8 & 24.6 & 26.1 & 26.1 & 17.6 \\
\hline & & $\mathbf{Y}$ & 28.1 & 26.3 & 26.5 & 26.4 & 26.9 & 26.9 & 23.8 \\
\hline & \multirow{2}{*}{ THA } & $\mathbf{X}$ & 147 & 158.5 & 159 & 158.2 & 157.2 & 157.2 & 150.2 \\
\hline & & $\mathbf{Y}$ & 150.4 & 159.2 & 157.7 & 158.4 & 155.4 & 155.4 & 145.8 \\
\hline \multirow{6}{*}{ 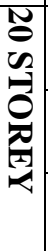 } & \multirow{2}{*}{ ESA } & $\mathbf{X}$ & 55.5 & 48.2 & 48.3 & 48 & 50.7 & 50.7 & 39.8 \\
\hline & & $\mathbf{Y}$ & 54.8 & 51.9 & 52.2 & 52 & 52.8 & 52.8 & 50.1 \\
\hline & \multirow{2}{*}{ RSA } & $\mathbf{X}$ & 39.2 & 33.9 & 34.1 & 33.8 & 36 & 36 & 25.8 \\
\hline & & $\mathbf{Y}$ & 38.8 & 36.7 & 36.9 & 36.8 & 37.4 & 37.4 & 33.7 \\
\hline & \multirow{2}{*}{ THA } & $\mathbf{X}$ & 415.7 & 236.6 & 241.4 & 233.1 & 312 & 312 & 154.5 \\
\hline & & $\mathbf{Y}$ & 396.8 & 321 & 332 & 326.5 & 350.8 & 350.8 & 212.2 \\
\hline \multirow{6}{*}{ 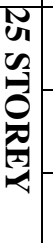 } & \multirow{2}{*}{ ESA } & $\mathbf{X}$ & 70.6 & 61.8 & 62 & 61.6 & 64.7 & 64.7 & 53.1 \\
\hline & & $\mathbf{Y}$ & 70.6 & 67.3 & 67.6 & 67.4 & 68.2 & 68.2 & 65.2 \\
\hline & \multirow[b]{2}{*}{ RSA } & $\mathbf{X}$ & 49.6 & 43.4 & 43.5 & 43.3 & 45.7 & 45.7 & 34.7 \\
\hline & & $\mathbf{Y}$ & 49.3 & 47.1 & 47.4 & 47.2 & 47.8 & 47.8 & 43.9 \\
\hline & \multirow{2}{*}{ THA } & $\mathbf{X}$ & 529.3 & 484.4 & 485.8 & 482.9 & 488.9 & 488.9 & 213.2 \\
\hline & & $\mathbf{Y}$ & 527.9 & 501 & 503 & 501.3 & 508.4 & 508.4 & 492 \\
\hline
\end{tabular}

ESA

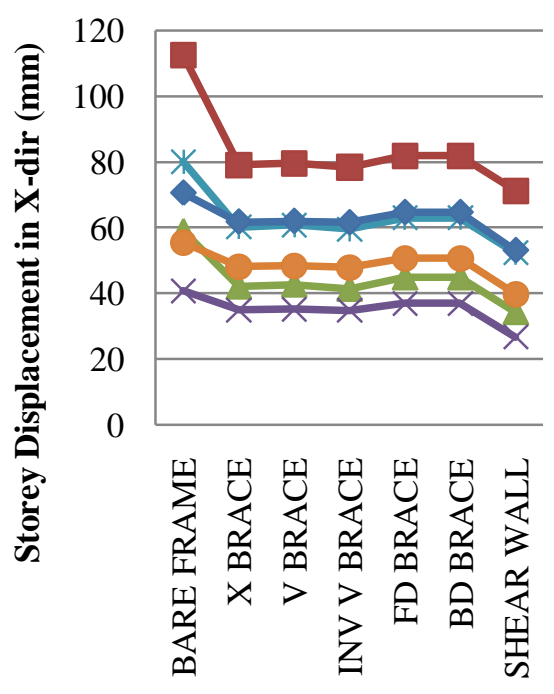

ESA

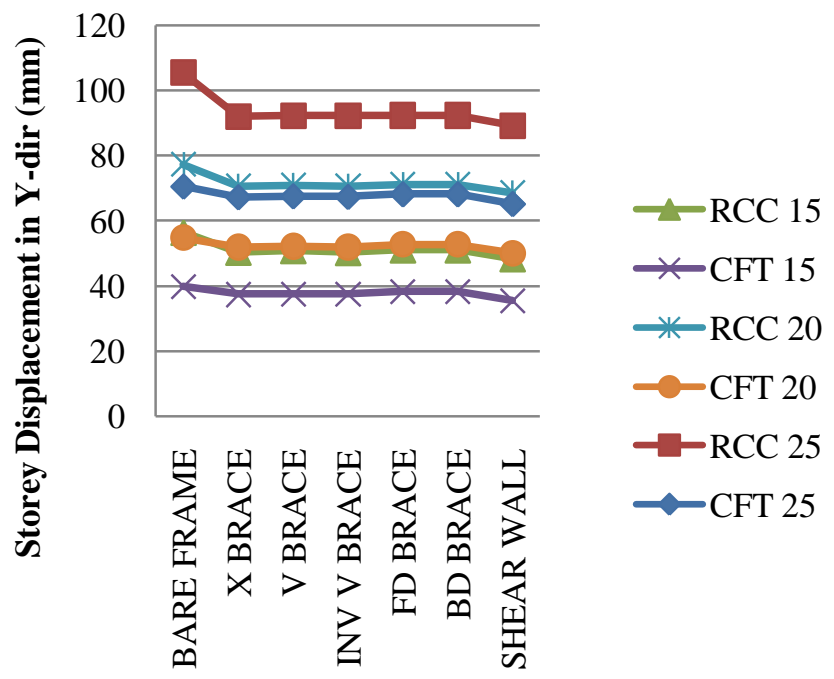

Chart 4: Comparison of top storey displacement by ESA method 

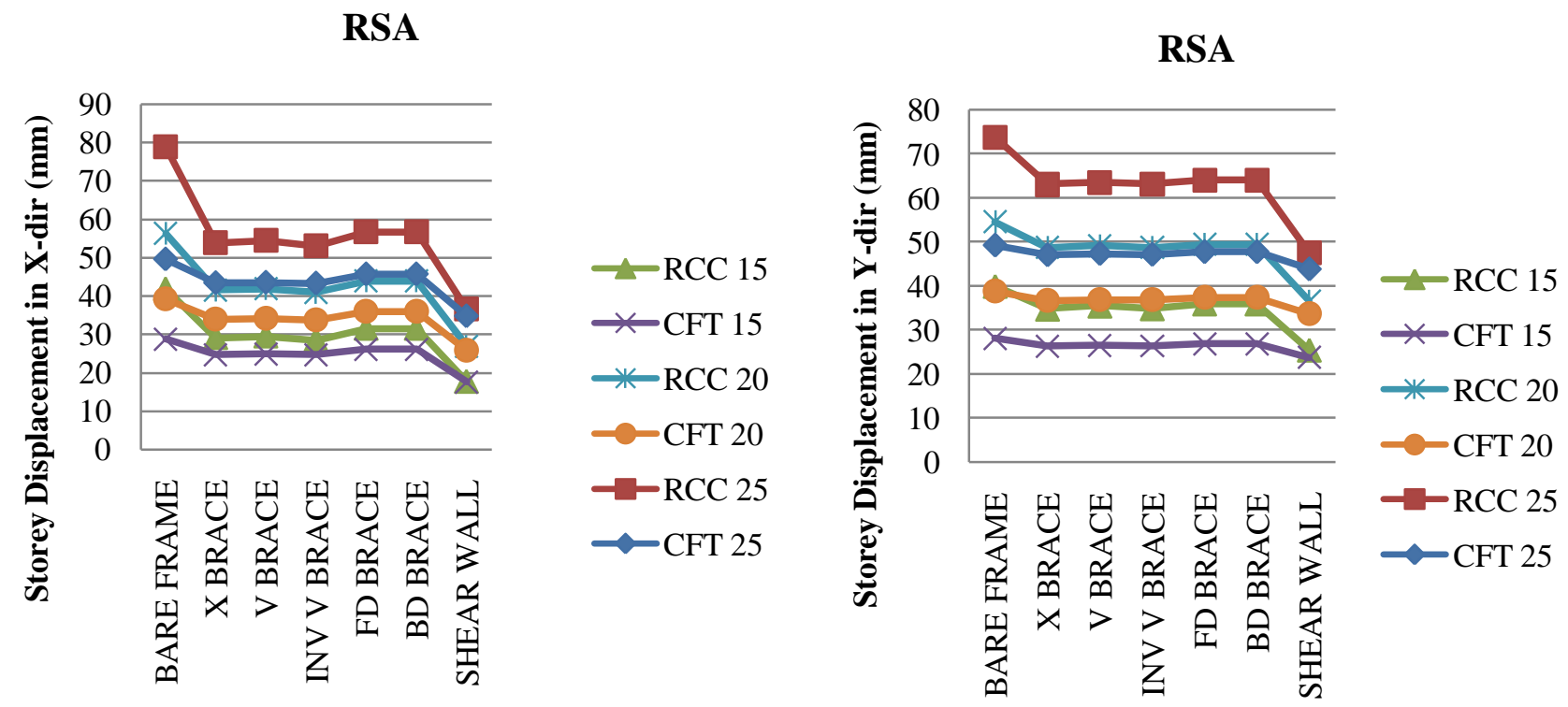

Chart 5: Comparison of top storey displacement by RSA method

THA

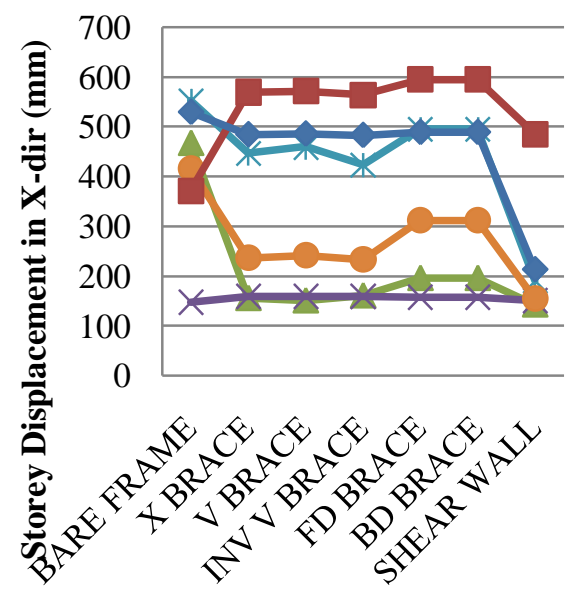

$\leftarrow$ RCC 15

$*$ CFT 15

* RCC 20

-CFT 20

$\rightarrow$ RCC 25

$\leadsto$ CFT 25

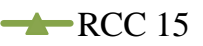

* CFT 15

* $\mathrm{RCC} 20$

-CFT 20

$\rightarrow$ RCC 25

$\leadsto$ CFT 25

THA

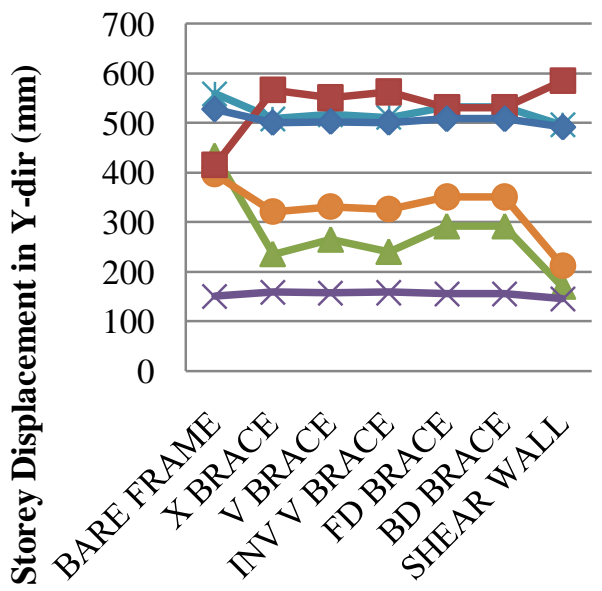

$\simeq$ RCC 15

- CFT 15

* RCC 20

- CFT 20

$\rightarrow-\mathrm{RCC} 25$

$\leadsto$ CFT 25

Chart 6: Comparison of top storey displacement by THA method

From the tables and figures, it is observed that the displacement values are higher for the bare frame model as compared to the other models. It is observed that displacement values in the transverse direction is more than the corresponding displacement in the longitudinal direction .When bracings are taken into consideration $\mathrm{X}$ and inverted $\mathrm{V}$ bracing are showing considerable reduction in displacement. When Shear wall is taken into consideration, it shows least displacement compared to bracings and bare frame. The displacement values linearly vary from ground to top floors in both the directions.

In case of ESA and RSA, Shear wall and X bracing shows good responses than all other bracing models and bare frame with maximum decrease in storey displacement at the top storey level. In case of CFT, Storey Displacement reduces upto $33 \%$ in Bare Frame, 20\% with Bracings, 24\% with Shear Walls by Equivalent Static Method. In case of response spectrum analysis there is reduction of $33 \%$ in Bare Frame, $18 \%$ in frames with Bracings and 5\% with Shear Walls. Therefore Storey displacement increases for RCC buildings and decreases for CFT buildings of 15, 20 and 25 storeys in equivalent static analysis and response spectrum analysis. Time history analysis is showing huge displacement values at top storey, because of huge acceleration. Therefore it can be concluded that influence of concrete bracings can considerably reduces storey displacement. 


\subsection{Storey Drifts}

The total lateral displacement that occurs in a single story of a multi-story building is known as storey drift. Drift in building frames is a result of flexural and shear mode contributions due to the column axial deformations and to the diagonal and beams deformations respectively. In low rise braced structures, the shear mode displacements are the most significant and will largely determine the lateral stiffness of the structure. In medium to high rise structures, higher is the axial forces and deformations in the columns and the accumulation of their effects over a greater height cause the flexural component of displacement to become dominant. The maximum storey drifts for various building models along longitudinal and transverse direction obtained from ETABS are shown in tables and figures below.

Table 7: Storey drift for RCC building by ESA method

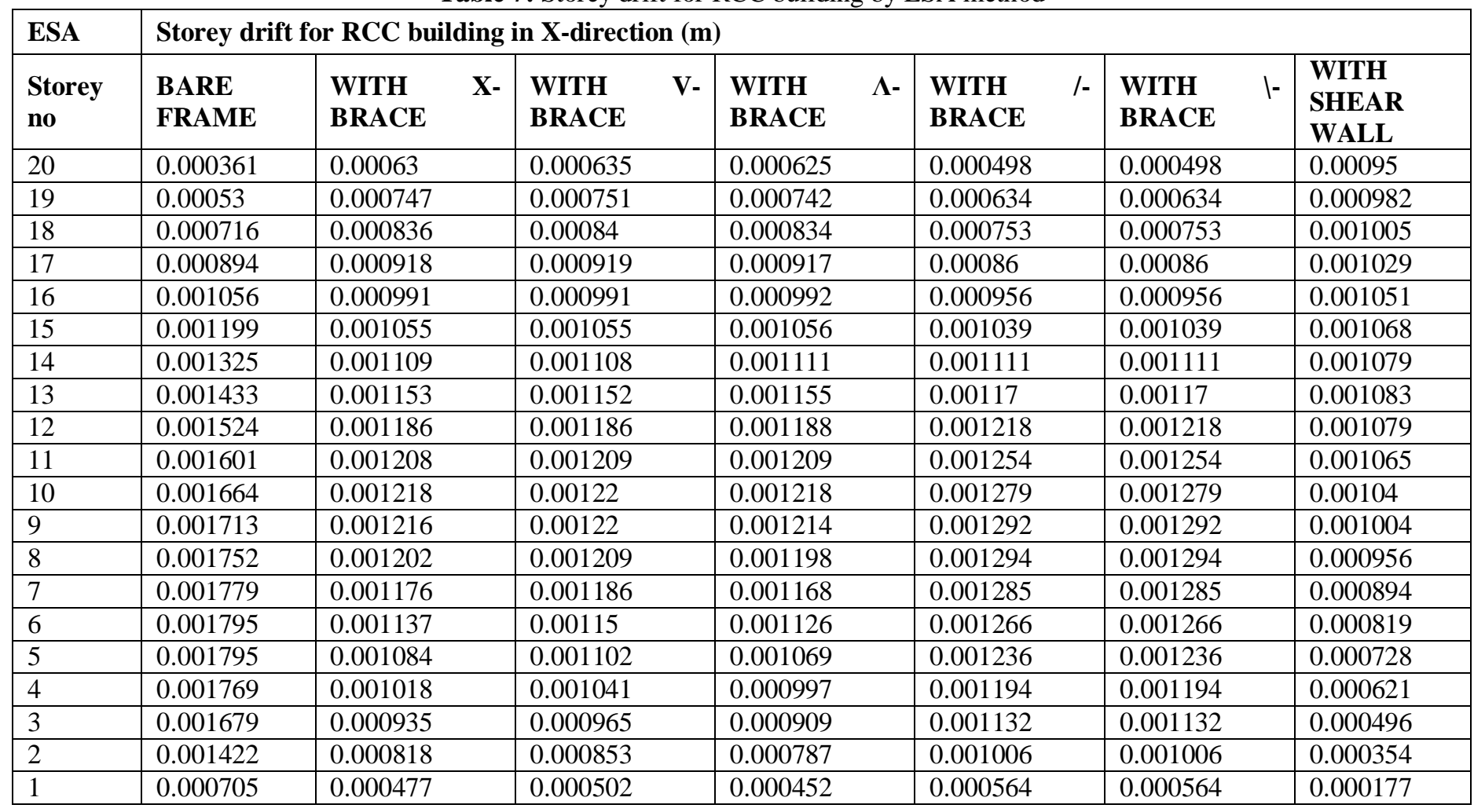

Table 8: Storey drift for CFT building by ESA method

\begin{tabular}{|c|c|c|c|c|c|c|c|}
\hline ESA & Storey dri & or CFT building & n X-direction (m) & & & & \\
\hline $\begin{array}{l}\text { Storey } \\
\text { no }\end{array}$ & $\begin{array}{l}\text { BARE } \\
\text { FRAME }\end{array}$ & $\begin{array}{l}\text { WITH } \\
\text { BRACE }\end{array}$ & $\begin{array}{l}\text { WITH } \\
\text { BRACE }\end{array}$ & $\begin{array}{l}\text { WITH } \\
\text { BRACE }\end{array}$ & $\begin{array}{l}\text { WITH } \\
\text { BRACE }\end{array}$ & $\begin{array}{l}\text { WITH } \\
\text { BRACE }\end{array}$ & $\begin{array}{l}\text { WITH } \\
\text { SHEAR } \\
\text { WALL }\end{array}$ \\
\hline 20 & 0.000256 & 0.000269 & 0.000271 & 0.000265 & 0.000249 & 0.000249 & 0.000639 \\
\hline 19 & 0.000372 & 0.000372 & 0.000375 & 0.000368 & 0.000356 & 0.000356 & 0.000676 \\
\hline 18 & 0.0005 & 0.000479 & 0.000481 & 0.000475 & 0.000472 & 0.000472 & 0.000702 \\
\hline 17 & 0.000623 & 0.000578 & 0.00058 & 0.000575 & 0.000582 & 0.000582 & 0.000729 \\
\hline 16 & 0.000734 & 0.000667 & 0.000668 & 0.000664 & 0.00068 & 0.00068 & 0.000755 \\
\hline 15 & 0.000833 & 0.000745 & 0.000746 & 0.000742 & 0.000767 & 0.000767 & 0.000778 \\
\hline 14 & 0.000919 & 0.000812 & 0.000814 & 0.00081 & 0.000843 & 0.000843 & 0.000796 \\
\hline 13 & 0.000994 & 0.00087 & 0.000871 & 0.000868 & 0.000908 & 0.000908 & 0.000808 \\
\hline 12 & 0.001056 & 0.000917 & 0.000919 & 0.000916 & 0.000962 & 0.000962 & 0.000814 \\
\hline 11 & 0.001109 & 0.000956 & 0.000958 & 0.000955 & 0.001007 & 0.001007 & 0.000813 \\
\hline 10 & 0.001151 & 0.000987 & 0.000989 & 0.000986 & 0.001043 & 0.001043 & 0.000802 \\
\hline 9 & 0.001185 & 0.001009 & 0.001012 & 0.001008 & 0.001071 & 0.001071 & 0.000783 \\
\hline 8 & 0.001211 & 0.001024 & 0.001027 & 0.001023 & 0.001092 & 0.001092 & 0.000754 \\
\hline 7 & 0.001229 & 0.001033 & 0.001036 & 0.001031 & 0.001106 & 0.001106 & 0.000714 \\
\hline 6 & 0.001239 & 0.001034 & 0.001038 & 0.001032 & 0.001113 & 0.001113 & 0.000662 \\
\hline 5 & 0.001238 & 0.001028 & 0.001032 & 0.001026 & 0.001112 & 0.001112 & 0.000598 \\
\hline 4 & 0.001219 & 0.001011 & 0.001016 & 0.001009 & 0.001097 & 0.001097 & 0.00052 \\
\hline
\end{tabular}




\begin{tabular}{|l|l|l|l|l|l|l|l|}
\hline 3 & 0.001156 & 0.000969 & 0.000975 & 0.000966 & 0.00105 & 0.00105 & 0.000426 \\
\hline 2 & 0.000979 & 0.000848 & 0.000853 & 0.000845 & 0.000908 & 0.000908 & 0.000318 \\
\hline 1 & 0.000488 & 0.00045 & 0.000452 & 0.000447 & 0.000469 & 0.000469 & 0.000169 \\
\hline
\end{tabular}

Table 9: Storey drift for RCC building by RSA method

\begin{tabular}{|c|c|c|c|c|c|c|c|}
\hline RSA & Storey dri & or RCC building & in X-direction ( $\mathrm{m}$ & & & & \\
\hline $\begin{array}{l}\text { Storey } \\
\text { no }\end{array}$ & $\begin{array}{l}\text { BARE } \\
\text { FRAME }\end{array}$ & $\begin{array}{l}\text { WITH } \\
\text { BRACE }\end{array}$ & $\begin{array}{l}\text { WITH } \\
\text { BRACE }\end{array}$ & $\begin{array}{l}\text { WITH } \\
\text { BRACE }\end{array}$ & $\begin{array}{l}\text { WITH } \\
\text { BRACE }\end{array}$ & $\begin{array}{l}\text { WITH } \\
\text { BRACE }\end{array}$ & $\begin{array}{l}\text { WITH } \\
\text { SHEAR } \\
\text { WALL }\end{array}$ \\
\hline 20 & 0.000318 & 0.00046 & 0.000463 & 0.000458 & 0.000367 & 0.000367 & 0.000505 \\
\hline 19 & 0.000465 & 0.000555 & 0.000557 & 0.000554 & 0.000478 & 0.000478 & 0.000523 \\
\hline 18 & 0.000607 & 0.000628 & 0.000629 & 0.000629 & 0.000574 & 0.000574 & 0.000536 \\
\hline 17 & 0.000721 & 0.000687 & 0.000687 & 0.000691 & 0.000652 & 0.000652 & 0.000547 \\
\hline 16 & 0.000811 & 0.000734 & 0.000734 & 0.000739 & 0.000713 & 0.000713 & 0.000555 \\
\hline 15 & 0.000888 & 0.000771 & 0.00077 & 0.000777 & 0.000761 & 0.000761 & 0.00056 \\
\hline 14 & 0.000961 & 0.000799 & 0.000798 & 0.000805 & 0.000802 & 0.000802 & 0.000562 \\
\hline 13 & 0.001031 & 0.00082 & 0.00082 & 0.000827 & 0.000837 & 0.000837 & 0.000561 \\
\hline 12 & 0.001096 & 0.000836 & 0.000836 & 0.000842 & 0.000866 & 0.000866 & 0.000556 \\
\hline 11 & 0.001156 & 0.000846 & 0.000847 & 0.000853 & 0.000891 & 0.000891 & 0.000548 \\
\hline 10 & 0.001212 & 0.000853 & 0.000855 & 0.000859 & 0.000911 & 0.000911 & 0.000536 \\
\hline 9 & 0.001266 & 0.000857 & 0.00086 & 0.000861 & 0.000929 & 0.000929 & 0.00052 \\
\hline 8 & 0.001316 & 0.000857 & 0.000863 & 0.00086 & 0.000943 & 0.000943 & 0.000499 \\
\hline 7 & 0.001361 & 0.000854 & 0.000861 & 0.000854 & 0.000954 & 0.000954 & 0.000473 \\
\hline 6 & 0.001401 & 0.000846 & 0.000856 & 0.000844 & 0.000962 & 0.000962 & 0.00044 \\
\hline 5 & 0.001437 & 0.000832 & 0.000845 & 0.000827 & 0.000966 & 0.000966 & 0.000399 \\
\hline 4 & 0.001458 & 0.00081 & 0.000827 & 0.000802 & 0.000966 & 0.000966 & 0.000349 \\
\hline 3 & 0.001426 & 0.000776 & 0.000797 & 0.000763 & 0.00095 & 0.00095 & 0.000287 \\
\hline 2 & 0.001236 & 0.000709 & 0.000732 & 0.000692 & 0.000872 & 0.000872 & 0.000213 \\
\hline 1 & 0.000621 & 0.000427 & 0.000443 & 0.000413 & 0.000499 & 0.000499 & 0.000115 \\
\hline
\end{tabular}

Table 10: Storey drift for CFT building by RSA method

\begin{tabular}{|c|c|c|c|c|c|c|c|}
\hline RSA & Storey dr & or CFT building & n X-direction (m) & & & & \\
\hline $\begin{array}{l}\text { Storey } \\
\text { no }\end{array}$ & $\begin{array}{l}\text { BARE } \\
\text { FRAME }\end{array}$ & $\begin{array}{l}\text { WITH X- } \\
\text { BRACE }\end{array}$ & $\begin{array}{l}\text { WITH } \\
\text { BRACE }\end{array}$ & $\begin{array}{l}\text { WITH } \quad \Lambda \text { - } \\
\text { BRACE }\end{array}$ & $\begin{array}{l}\text { WITH } \\
\text { BRACE }\end{array}$ & $\begin{array}{l}\text { WITH } \\
\text { BRACE }\end{array}$ & $\begin{array}{l}\text { WITH } \\
\text { SHEAR } \\
\text { WALL }\end{array}$ \\
\hline 20 & 0.000205 & 0.000202 & 0.000203 & 0.000199 & 0.000193 & 0.000193 & 0.000422 \\
\hline 19 & 0.000301 & 0.000285 & 0.000287 & 0.000283 & 0.000281 & 0.000281 & 0.000447 \\
\hline 18 & 0.000399 & 0.000369 & 0.000371 & 0.000367 & 0.000372 & 0.000372 & 0.000464 \\
\hline 17 & 0.000484 & 0.000442 & 0.000443 & 0.00044 & 0.00045 & 0.00045 & 0.000482 \\
\hline 16 & 0.000554 & 0.000502 & 0.000503 & 0.0005 & 0.000516 & 0.000516 & 0.000497 \\
\hline 15 & 0.000614 & 0.000552 & 0.000553 & 0.00055 & 0.000571 & 0.000571 & 0.00051 \\
\hline 14 & 0.000667 & 0.000593 & 0.000595 & 0.000592 & 0.000618 & 0.000618 & 0.00052 \\
\hline 13 & 0.000714 & 0.000629 & 0.00063 & 0.000627 & 0.000659 & 0.000659 & 0.000527 \\
\hline 12 & 0.000758 & 0.000659 & 0.00066 & 0.000658 & 0.000695 & 0.000695 & 0.00053 \\
\hline 11 & 0.000797 & 0.000685 & 0.000687 & 0.000684 & 0.000728 & 0.000728 & 0.00053 \\
\hline 10 & 0.000835 & 0.00071 & 0.000712 & 0.000709 & 0.000758 & 0.000758 & 0.000525 \\
\hline 9 & 0.000871 & 0.000734 & 0.000736 & 0.000733 & 0.000788 & 0.000788 & 0.000516 \\
\hline 8 & 0.000905 & 0.000757 & 0.000759 & 0.000756 & 0.000817 & 0.000817 & 0.000502 \\
\hline 7 & 0.000938 & 0.00078 & 0.000783 & 0.000779 & 0.000845 & 0.000845 & 0.000481 \\
\hline 6 & 0.000969 & 0.000802 & 0.000805 & 0.000801 & 0.000873 & 0.000873 & 0.000453 \\
\hline 5 & 0.000995 & 0.000821 & 0.000825 & 0.00082 & 0.000897 & 0.000897 & 0.000416 \\
\hline 4 & 0.001008 & 0.000834 & 0.000838 & 0.000832 & 0.000912 & 0.000912 & 0.000368 \\
\hline 3 & 0.000982 & 0.000823 & 0.000827 & 0.000821 & 0.000897 & 0.000897 & 0.000309 \\
\hline 2 & 0.000848 & 0.000736 & 0.000739 & 0.000733 & 0.000792 & 0.000792 & 0.000238 \\
\hline 1 & 0.000428 & 0.000395 & 0.000397 & 0.000393 & 0.000414 & 0.000414 & 0.000133 \\
\hline
\end{tabular}


STOREY DRIFT FOR RCC BUILDING

(ESA)

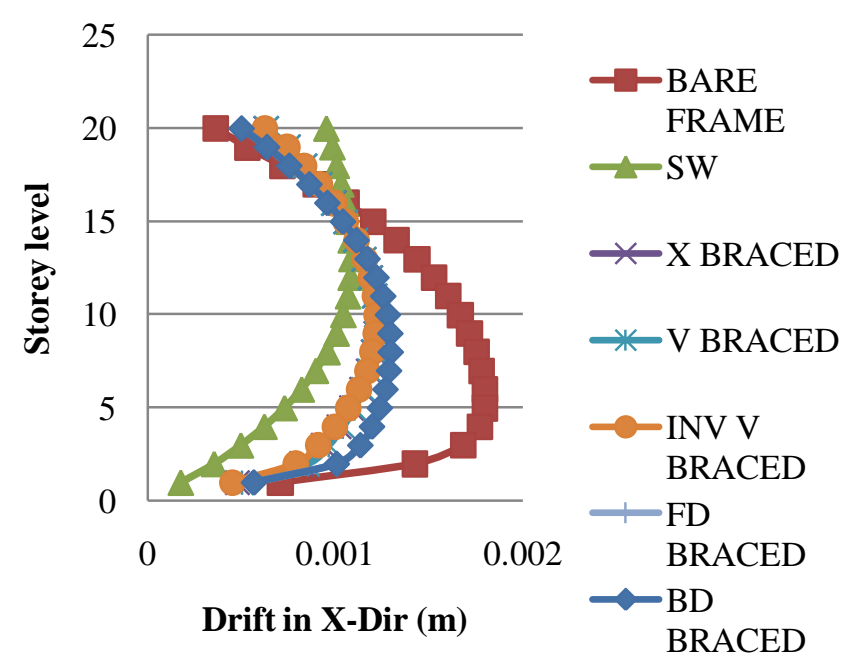

STOREY DRIFT FOR CFT BUILDING

(ESA)

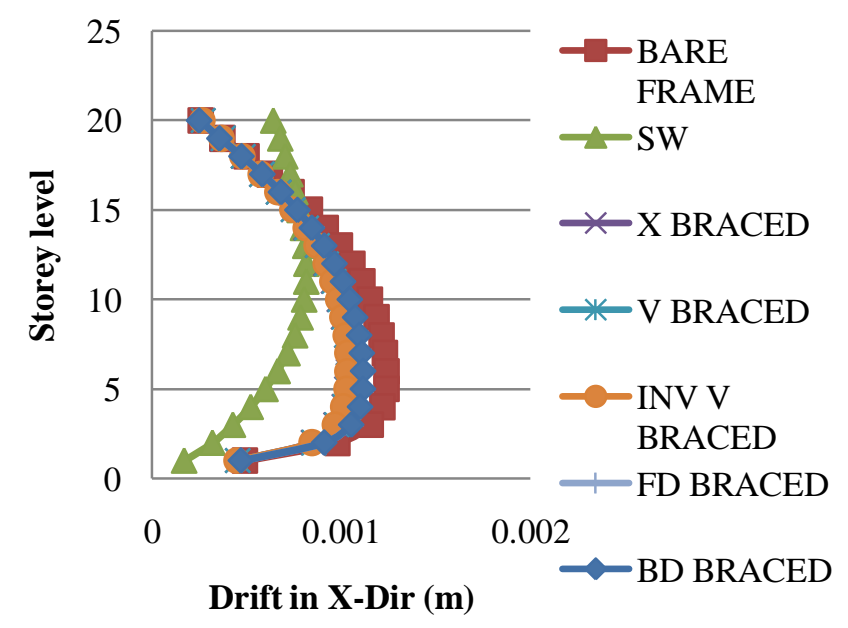

Chart 7: Comparison of Storey Drift for RCC and CFT building by ESA method

STOREY DRIFT FOR RCC BUILDING (RSA)

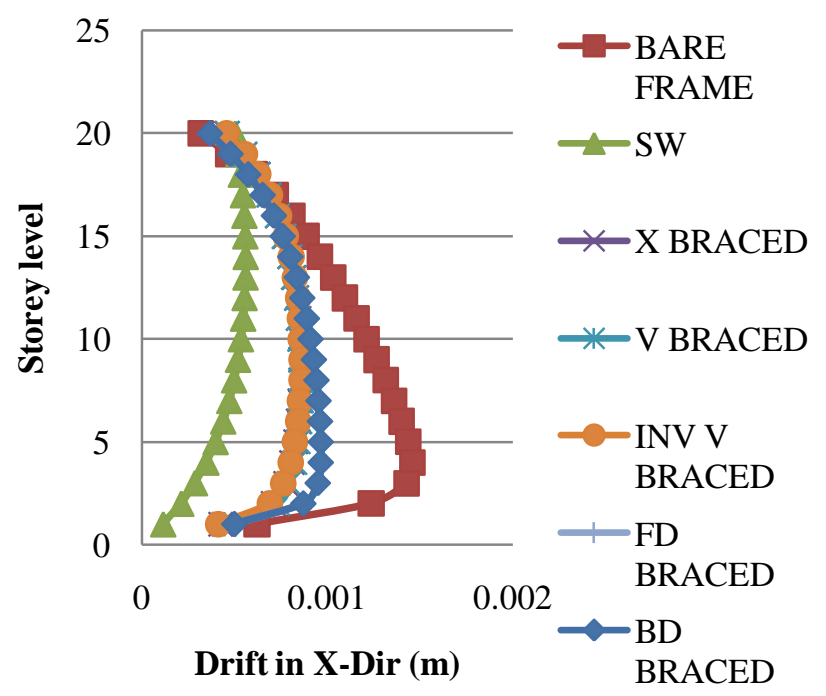

STOREY DRIFT FOR CFT BUILDING (RSA)

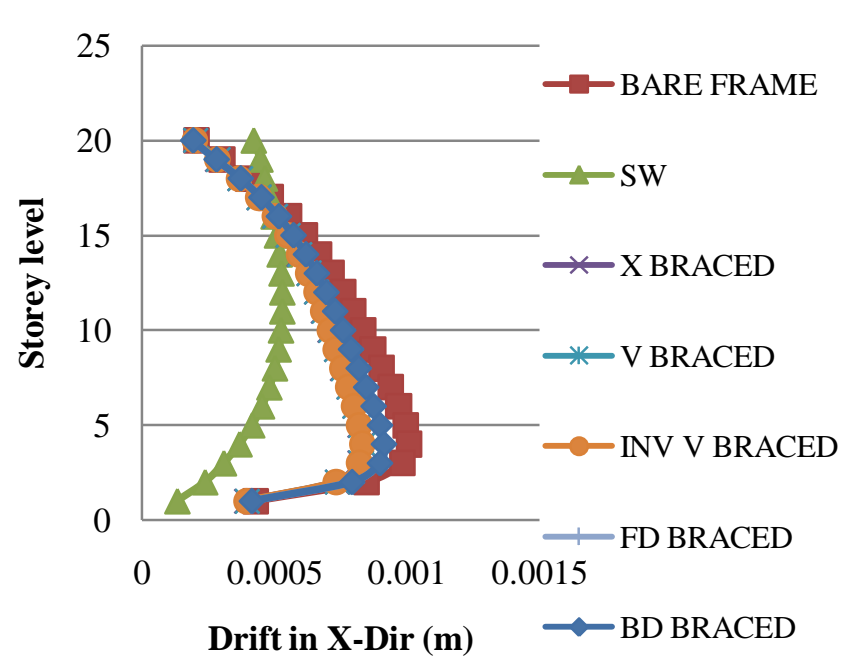

Chart 8: Comparison of Storey Drift for RCC and CFT building by ESA method

From tables, the drift values gradually increases from storey 5 to storey 15 and then start decreasing from storey 16 of 20 storeys of RCC and composite CFT buildings in Xdirections as shown in figures. Also the storey drift in both the directions satisfy the permissible limit i.e $0.004 * \mathrm{~h}=0.004 * 3.0=0.012 \mathrm{~m}=12 \mathrm{~mm}$. Storey Drift values are found within the permissible limit specified by the IS CODE 1893-2002, when different bracing systems and shear wall incorporating in models, the storey drift got reduced for ESA and RSA and found in the permissible limits. When bracings are taken into consideration, $\mathrm{X}$ bracings shows considerable reduction in storey drift when compared with bare frame. While taking Shear wall into consideration, it shows the least reduction compared to bare frame and different types of bracings system in case of equivalent static method of analysis and response spectrum method of analysis. Shear wall and $\mathrm{X}$ bracings gives much strength and stiffness when subjected to earthquake loading. As from above tables and charts, Response spectrum analysis are showing very much non-linear behaviour and simulating to practical situation which then helps the designer to choose proper analysis procedure. 


\section{CONCLUSION}

\subsection{Fundamental Time Period and Frequency}

- Fundamental time period decreases by providing different types of bracings and shear wall in the building frames.

- Time period increases with increase in number of storeys while frequency decreases.

- Time period for RCC buildings is greater than CFT buildings at different modes and can be reduced by using bracings and shearwalls, when compared with bare frame.

\subsection{Storey Displacement}

- Displacement reduces with introducing bracings and shearwalls for both RCC and CFT buildings, when compared with bare frame displacement.

- Displacement is more for RCC when compared with CFT building with respect to ESA, RSA as well as THA methods.

- Increase in number of stories increases the lateral displacement along both the directions.

\subsection{Storey Drift}

- $\quad$ Storey drifts are found within the permissible limit as specified in clause 7.11.1 of IS1893-2002.

- Storey drift for RCC buildings is greater than CFT buildings for both ESA and RSA methods.

- Using bracings and shearwalls storey drift can be minimized.

\section{REFERENCES}

[1] Ketan Patel and Sonal Thakkar "Analysis of CFT, RCC and STEEL building subjected to lateral loading" Procedia Engineering 51 ( 2013 ) 259 - 265

[2] X.T. SI and Francis T.K. AU "An Efficient Method for Time-Dependent Analysis of Composite Beams" Procedia Engineering 14 (2011) 1863-1870

[3] Š. Gramblička and A. Lelkes "Analysis of composite steel-concrete columns" Procedia Engineering 40 ( 2012 ) $247-252$

[4] Gianluca Ranzi, Graziano Leoni, Riccardo Zandonini "State of the art on the time-dependent behaviour of composite steel-concrete structures" Journal of Constructional Steel Research 80 (2013) 252-263

[5] Mahesh Suresh Kumawat, L.G.Kalurkar "Static \& dynamic analysis of multistory building using composite structure" International Journal of Research in Engineering and Technology Volume: 03 May-2014

[6] Umesh.R.Biradar and Shivaraj Mangalgi "Seismic response of reinforced concrete structure by using different bracing systems" International Journal of Research in Engineering and Technology Volume: 03 Issue: 09 Sep-2014.

[7] Kulkarni J. G., Kore P. N., Tanawade S. B. " Seismic Response Of Reinforced Concrete Braced Frames" International Journal of Engineering Research and
Applications (IJERA) Vol. 3, Issue 4, Jul-Aug 2013, pp.1047-1053.

[8] Nauman Mohammed, Islam Nazrul "Behaviour of Multi-storey RCC Structure with Different Type of Bracing System (A Software Approach)" International Journal of Innovative Research in Science, Engineering and Technology Vol. 2, Issue 12, December 2013.

[9] Shahzad Jamil Sardar and Umesh. N. Karadi "Effect of change in shear wall location on storey drift of multi-storey building subjected to lateral loads" International Journal of Innovative Research in Science, Engineering and Technology Vol. 2, Issue 9, September 2013.

[10] ETABS Non-linear "Extended 3-D analysis of the building systems", California, Computers and structures Inc., Berkeley.

[11] IS 456: 2000. "Indian Standard Code of Practice for plain and reinforced Concrete", Bureau of Indian Standards, New Delhi.

[12] IS 875: 1987. "Code of practice for design loads (other than earthquake) for building and structures Part2: Imposed loads", Bureau of Indian Standards New Delhi.

[13] IS 1893(Part-I) 2002: Criteria for Earthquake Resistant Design of Structures, Part-I General Provision and Buildings (Fifth Revision). Bureau of Indian Standards, New Delhi.

[14] IS 13920: 1993. "Indian Standard Code of the practice for the detailing of Reinforced Concrete Structures Subjected to Seismic Forces" Bureau of Indian Standards, New Delhi.

[15] R.P.Johnson, "Composite structures of steel and concrete" Volume, Blackwell Scientific publications, UK.1994.

\section{BIOGRAPHIES}

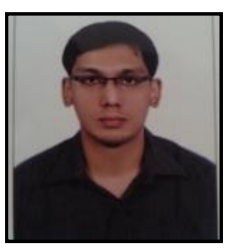

Faizulla $Z$ Shariff $P G$ student in Structural Engineering at SVCE, Bangalore and obtained his B.E. in Civil Engineering from Brindavan College of Engineering, Bangalore.

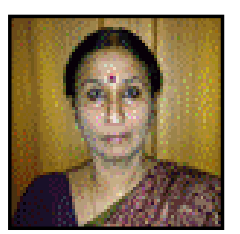

Suma Devi obtained her M.E. in Earthquake Engineering from Bangalore University and B.Tech in Civil Engineering from Calicut University. She has 11 years industrial experience in residential, commercial, infrastructure projects \& 15 years of academic experience. 